\title{
Czy globalizacja wspiera korupcję?
}

Anna Maria Pluskota*

\section{Wstęp}

Korupcja jest zjawiskiem obserwowanym od starożytności. Grecki historyk Herodot (2008, s. 299) opisał historię z VI w. p.n.e. skorumpowanego sędziego Sisamnesa, którego król Kambiznes ukarał za łapownictwo śmiercią, zaś jego skórą kazał obić sędziowski fotel, na którym zasiadł syn Sisamnesa. W Rzymie korupcja dotykała gubernatorów prowincji, właścicieli fabryk, dzierżawców kopalń, jak również poborców podatkowych (Stachowicz-Stanusch, Sworowska 2012, s. 101). W starożytnej Grecji karą dziesięciokrotności wartości łapówki były karane osoby zarówno przyjmujące, jak i wręczające łapówki, zaś drakońską karą było skazanie tych osób na śmierć (Walczak-Duraj 2010, s. 264). Mimo to korupcja przetrwała aż do czasów obecnych ${ }^{1}$. Co więcej występuje ona niezależnie od ustroju politycznego, tradycji kulturowych czy dominującej na danym terenie religii.

Analizując zjawisko korupcji, można się spotkać z wieloma jej definicjami. Trafną definicją wydaje się definicja zaproponowana w cywilnoprawnej konwencji o korupcji z 4 listopada 1999 r. w Strasburgu: korupcja jest żądanie, proponowanie, wręczanie lub przyjmowanie, bezpośrednio lub pośrednio, łapówki lub jakiejkolwiek innej nienależnej korzyści lub jej obietnicy, które wypacza prawidtowe wykonywanie jakiegokolwiek obowiazku lub zachowanie wymagane od osoby otrzymującej łapówke, nienależna korzyść lub jej obietnicę (Cywilnoprawna

\footnotetext{
* Anna Maria Pluskota - magister, Uniwersytet Łódzki, Wydział Ekonomiczno-Socjologiczny, Katedra Finansów Korporacji, e-mail: anna.pluskota@uni.lodz.pl.

${ }^{1}$ Mimo przemian kulturowych i gospodarczych korupcja nie została wyeliminowana z życia społecznego. Jest ona obecnie ważnym problemem będącym w centrum zainteresowań badaczy ekonomicznych. Ekonomiczna analiza korupcji rozkwitła w latach 90. XX w., kiedy to organizacja Transparency International po raz pierwszy opublikowała wiarygodny i uznawany miernik percepcji korupcji. Obecnie indeks percepcji korupcji jest obliczany dla 167 państw (www.transparency.org).
} 
konwencja o korupcji... 1999). Definicja ta podkreśla negatywny wpływ korupcji na ład gospodarczy i polityczny danego państwa. W wyniku zmowy między co najmniej dwiema osobami następuje czyn wypaczający prawidłowe wykonywanie obowiązku lub zachowania. Osoby te stają się w tym momencie przestępcami. Powtarzające się tego typu przestępstwa, których sprawcy nie zostali ukarani, tworzą swoiste przyzwolenie na łamanie prawa, które uderza w przestrzeganie porządku prawnego w państwie przez obywateli.

Jako że większość definicji jest niedoskonała, korupcję można trafniej opisać, charakteryzując jej główne formy: łapownictwo, nepotyzm, płatną protekcję. Jednakże ze względu na różnice kulturowe akty korupcji w jednym kraju mogą zostać uznane za przestępstwo, zaś w innym są obowiązującym elementem kultury, np. w państwach muzułmańskich zwyczajowo wręcza się urzędnikom prezenty (Mindur 2006, s. 75).

Sposób postrzegania korupcji przez społeczeństwo ewoluuje również w czasie. Do 1977 r. amerykańskie firmy mogły legalnie wręczać łapówki w celu zawarcia kontraktu za granicą, a $w$ wielu krajach tego typu zachęty byty legalne do $1997 r$. (Bodislav i in. 2016, s. 164). Wszędzie tam, gdzie jest mowa o korupcji wynikającej z przekroczenia uprawnień, interpretacja tego zachowania może być różna w zależności od kulturowych uwarunkowań społeczeństwa. Najczęściej to obywatele - za pomocą obowiązujących przepisów prawa - decydują, czy dana czynność jest uznawana za korupcję. Ich percepcja korupcji determinowana jest panującymi zwyczajami i kulturowym postrzeganiem moralności przy zawieraniu transakcji. Często w definicjach korupcji podkreśla się jej nieetyczny wymiar. Korupcja kojarzona jest z zachowaniami nieetycznymi, niemoralnymi, aspołecznymi, zmierzajacymi do wypaczenia ustalonego porzad$k u$ (Stachowicz-Stanusch, Sworowska 2012, s. 101). Należy jednak podkreślić, że nie wszystkie akty korupcji należy traktować jako nieetyczne. Istnieją przypadki korupcji w szlachetnym celu. Przykładem moralnego łapownictwa jest wręczanie łapówek w czasie II wojny światowej żołnierzom niemieckim przez Oscara Schindlera, który w ten sposób ratował od śmierci swoich pracowników pochodzenia żydowskiego.

Poniższy artykuł ma na celu udzielenie odpowiedzi na zadane w tytule pytanie: czy globalizacja wspiera korupcję? Globalizacja, jako proces zacieśniania i integracji państw, społeczeństw i kultur, nie spowodowała wyeliminowania przypadków korupcji. Jednakże wzrost otwartości i dostępności rynków zbytu między krajami powinien doprowadzić do zmniejszania skali korupcji - dzięki większej przejrzystości globalnych transakcji. W kolejnej części artykułu zaprezentowano przegląd literatury i wyniki analizy statystycznej dla 24 wybranych państw Europy. Całość zakończono podsumowaniem zawierającym najważniejsze wnioski $\mathrm{z}$ analizy literatury i wykorzystanych danych. 


\section{Korupcja a globalizacja - przegląd literatury}

Rozwój gospodarczy i związane z nim otwarcie rynków nie wyeliminowały korupcji. Wręcz przeciwnie, wydaje się, że korupcja staje się coraz bardziej powszechna. Wnioski z dotychczasowych badań są niejednoznaczne, jeśli chodzi o relację między korupcją a globalizacją.

Badinger i Nindl (2014, ss. 1424-1440) na podstawie danych panelowych badali uwarunkowania korupcji jako skutki globalizacji w kontekście występowania nierówności. Badania wykazały, że wzrost PKB p.c., polepszenie dostępu do edukacji lub zwiększenie praw politycznych zmniejszają korupcję. Jednak $\mathrm{w}$ ich badaniu wzrost renty $\mathrm{z}$ tytułu dostępności do zasobów naturalnych powoduje zwiększenie skorumpowania. Autorzy zauważyli, że globalizacja zmniejsza korupcję, lecz te efekty są bardziej widoczne w krajach rozwijających się.

Bodislav, Rotaru i Georgescu (2016, s. 174) na podstawie przeprowadzonych badań wykazali, że niski poziom konkurencyjności gospodarki prowadzi do większej korupcji urzędników. Według autorów korupcja jest większa w krajach, które chronią rodzimą przedsiębiorczość przed konkurencją z zagranicy, a zatem zwiększenie konkurencyjności gospodarki może być narzędziem walki z korupcją.

Torgler i Piatti (2013, s. 354) badali relacje między ogromnym bogactwem pojedynczych osób, globalizacją a korupcją. Autorzy wykazali, że globalizacja powoduje wzrost superbogactwa, ponieważ następuje zwiększenie swobody przepływu kapitału, informacji i towarów. Doszli również do wniosku, że nadmierne bogactwo jednostki wynika z działań korupcyjnych. Wskazali na dodatnią korelację między superbogactwem a korupcją. W środowiskach skorumpowanych fortuny są w posiadaniu niewielkiej liczby ludzi.

W literaturze można znaleźć informacje, że optymalny poziom korupcji w gospodarce jest niezerowy (Klitgaard 1988, ss. 24-27). Dzhumashev (2014, s. 211) jednoznacznie wykazał na podstawie modelu matematycznego możliwość istnienia niezerowej wielkości korupcji, która maksymalizowałaby stopę wzrostu gospodarczego. Heckelman i Powell (2010, ss. 351-378) za pomocą analizy ekonometrycznej wykazali, że korupcja może być pomocna dla rozwoju gospodarczego części państw rozwijających się: korupcja może zwiększyć wzrost poprzez umożliwienie jednostkom płacenia lapówek $w$ celu ominięcia nieefektywnych przepisów i opóźnień biurokratycznych (Heckelman, Powell 2010, s. 352).

Badania Ewoh, Matei i Matei (2013, ss. 7-34) dotyczące wybranych państw Europy Południowo-Wschodniej pozwoliły na obiektywne zbadanie relacji między globalizacją a korupcją w państwach europejskich borykających się ze skorumpowaniem społeczeństwa. Autorzy wykazali, że istnieje związek między postępującymi procesami globalizacyjnymi a zwiększającą się korupcją. Porównali korupcję do raka, który „toczy” gospodarkę w wyniku globalizacji rynków kapitałowych. Antidotum na zaistniałą sytuację ma być połączenie sił przez państwa w walce z korupcją na wszystkich szczeblach władzy politycznej. Zdaniem 
autorów jedynie powszechne działania państw mogą zwalczyć korupcję wynikającą z procesów globalizacyjnych.

Analiza literatury dostarczyła informacji o rozbieżnościach w najnowszych badaniach naukowych dotyczących korelacji globalizacji i korupcji. Otwiera to możliwość dalszego pogłębiania badań w tym zakresie. Następna część artykułu prezentuje przykład tego typu badań na danych pochodzących z 24 państw europejskich.

\section{Rozwój gospodarczy a percepcja korupcji w Europie}

Rozwój gospodarczy państw europejskich w ostatnich dziesięcioleciach był podyktowany zacieśniającą się współpracą w ramach Unii Europejskiej. Ta szczególna współpraca gospodarek nie ogranicza się jedynie do państw będących w Unii, lecz obejmuje częściowo również państwa stowarzyszone, np. Turcję. Zwiększająca się integracja państw jest podstawowym czynnikiem postępującej globalizacji. Możliwe jest zatem postawienie hipotezy, że w państwach europejskich, w połączeniu z procesami globalizacyjnymi, zmniejszyła się skala skorumpowania społeczeństwa, przy czym procesy globalizacyjne będą opisywane za pomocą wielkości wybranych mierników makroekonomicznych.

Analizując zależności między procesami globalizacyjnymi a korupcją, przeprowadzono badanie statystyczne na wybranych zmiennych dotyczących 24 państw europejskich. Dane statystyczne obejmowały okres od 1998 r. do 2015 r. W analizie statystycznej wykorzystano następujące zmienne:

1) PKB na mieszkańca (źródło: Bank Światowy, http://databank.worldbank. org) - produkt krajowy brutto przypadający na jednego mieszkańca jest jedną z miar rozwoju gospodarczego kraju. Wartości są podane w USD urealnionych na rok bazowy 2005 .

2) Przypływ bezpośrednich inwestycji zagranicznych netto jako procent PKB (źródło: Bank Światowy, http://databank.worldbank.org) - wartość inwestycji w danym kraju przeprowadzonych przez nierezydentów jako udział w PKB tego kraju. Miernik obejmuje jedynie nowe wpływy inwestycyjne pomniejszone o inwestycje wycofane.

3) Odpływ bezpośrednich inwestycji zagranicznych netto jako procent PKB (źródło: Bank Światowy, http://databank.worldbank.org) - wartość inwestycji dokonywanych przez obywateli danego kraju za granicą jako udział w PKB tego kraju.

4) Indeks Percepcji Korupcji (źródło: Transparency International, www. transparency.org) - syntetyczny wskaźnik korupcji podawany dla danego państwa. Opiera się on na badaniach sondażowych i jakościowych. Przyjmuje wartości od 0 pkt. (całkowicie skorumpowane państwo) do 100 pkt. (brak korupcji). 
W przypadku danych panelowych obliczono podstawowe statystyki opisowe. Do analizy wybrano państwa o różnym stopniu rozwoju gospodarczego mierzonego PKB na osobę. Najmniejszą wartość PKB per capita w bazie danych odnotowano w przypadku Bułgarii w 1999 r., zaś największą w przypadku Norwegii w 2007 r. Wartość odchylenia standardowego potwierdza wysokie zróżnicowanie danych dla PKB p.c. Średnie udziały przypływów i odpływów inwestycji w PKB przyjmują zbliżone wartości. Indeks percepcji korupcji wskazuje na różne stopnie skorumpowania analizowanych państw. Najmniejszą wartość, 26 pkt., otrzymała Rumunia w 2002 r., zaś największą wartość, oznaczającą państwo wolne od korupcji, otrzymała Finlandia w 2000 r. i dwukrotnie Dania - w latach 1998 i 1999.

Tabela 1. Statystki opisowe wybranych zmiennych

\begin{tabular}{|l|c|c|c|c|}
\cline { 2 - 5 } \multicolumn{1}{c|}{} & Średnia & Odch. stand. & $\begin{array}{c}\text { Min. wielkość } \\
\text { zmiennej w okresie }\end{array}$ & $\begin{array}{c}\text { Maks. wielkość } \\
\text { zmiennej w okresie }\end{array}$ \\
\hline $\begin{array}{l}\text { PKB per } \\
\text { capita (USD) }\end{array}$ & 33393,90 & 21191,30 & 3750,49 & 91593,60 \\
\hline $\begin{array}{l}\text { Przypływ } \\
\text { inwestycji (\%) }\end{array}$ & 5,758 & 9,089 & $-16,091$ & 87,442 \\
\hline $\begin{array}{l}\text { Odpływ } \\
\text { inwestycji (\%) }\end{array}$ & 5,062 & 9,965 & $-37,445$ & 76,973 \\
\hline $\begin{array}{l}\text { Ind. korupcji } \\
\text { (pkt) }\end{array}$ & 66,44 & 20,66 & 26,00 & 100,00 \\
\hline
\end{tabular}

Źródło: opracowanie własne.

Weryfikacja hipotezy postawionej $\mathrm{w}$ artykule nastąpiła na podstawie danych dotyczących korelacji Pearsona (tabela 2) oraz różnic wartości PKB p.c. i indeksu percepcji korupcji w latach 1998 i 2015 (tabela 3). Korelacja między indeksem percepcji korupcji a PKB p.c. jest istotna statystycznie (wartość p-value - 0,00) i wynosi 0,82 . Jest to wysoka dodatnia korelacja wskazująca na ścisłe powiązanie skali korupcji z PKB p.c. Rozwój gospodarczy jest skorelowany ze zmniejszającą się skalą korupcji. Mierniki dotyczące przypływów i odpływów inwestycji netto mają niskie wartości korelacji z indeksem percepcji korupcji. Obie wielkości są jednak istotne pod względem statystycznym, ponieważ wartość p-value jest mniejsza od przyjętej wartości granicznej 0,05 . Interesujące jest to, że bardziej skorelowane ze wskaźnikiem skorumpowania są odpływy inwestycji netto niż przypływ bezpośrednich inwestycji zagranicznych. Oznacza to, że wraz ze wzrostem indeksu percepcji korupcji o 1 pkt przypływy inwestycji wzrosną jedynie o $0,09 \%$ PKB, zaś odpływy inwestycji o $0,33 \%$ PKB. Zwalczanie skorumpowania w kraju wiąże się raczej ze wzrostem inwestycji rodaków za granicą niż z inwestycjami podejmowanymi przez obcokrajowców w kraju. 
Tabela 2. Korelacja Pearsona dla wybranych zmiennych

\begin{tabular}{|l|c|}
\cline { 2 - 2 } \multicolumn{1}{c|}{} & Indeks percepcji korupcji \\
\hline PKB per capita & $0,8249(0,0000)$ \\
\hline Przypływ inwestycji & $0,0999(0,0380)$ \\
\hline Odpływ inwestycji & $0,3273(0,0000)$ \\
\hline
\end{tabular}

Źródło: opracowanie własne.

W celu dokładnej weryfikacji postawionej hipotezy sprawdzono, czy wzrost PKB na mieszkańca w latach 1998-2015 wiązał się ze wzrostem indeksu percepcji korupcji. Ze względu na niską korelację wskaźnika korupcji z miernikami przypływu i odpływu inwestycji pominięto je w dalszych obliczeniach. W tabeli 3 zamieszczono różnice dotyczące miernika rozwoju gospodarczego i wskaźnika korupcji między ich wartościami odnotowanymi w 1998 r. i w 2015 r. dla każdego z 24 wybranych państw osobno. Tylko w przypadku Włoch różnica między poziomami PKB na mieszkańca była ujemna. Wszystkie pozostałe państwa odnotowały wzrost rozwoju gospodarczego mierzonego tym parametrem.

Jeśli chodzi o różnice dotyczące indeksu percepcji korupcji, to ujemne wielkości wystąpiły w przypadku następujących państw: Danii, Finlandii, Islandii, Irlandii, Włoch, Holandii, Norwegii, Portugalii, Hiszpanii, Szwecji, Szwajcarii i Wielkiej Brytanii. Jest to dokładnie połowa państw biorących udział w badaniu i poza Włochami wszystkie z nich osiągnęły wzrost rozwoju gospodarczego w latach 1998-2015. Są to państwa, które miały wyższy produkt krajowy brutto na mieszkańca w 2015 r., tj. powyżej 20000 USD w stosunku do państw biedniejszych. $\mathrm{W}$ przypadku tych państw nie zaobserwowano pozytywnego skutku w walce z korupcją w połączeniu ze skutkami globalizacji. W przypadku państw słabiej rozwiniętych, tj. Bułgarii, Rumunii, Turcji, Łotwy, Węgier, Polski, Estonii i Słowacji, zauważalnemu pozytywnemu efektowi $\mathrm{w}$ walce $\mathrm{z}$ korupcją towarzyszy również wzrost miernika rozwoju gospodarczego. Wszystkie te państwa, poza Turcją, są członkami Unii Europejskiej. Możliwe zatem, że wraz z zachodzącymi procesami globalizacyjnymi w państwach słabiej rozwiniętych nastąpiła redukcja skorumpowania społeczeństwa. Postawiona hipoteza została częściowo potwierdzona.

Tabela 3. Różnice dla wybranych mierników między 1998 r. a 2015 r.

\begin{tabular}{|c|c|c|c|c|c|}
\hline Państwo & $\begin{array}{c}\text { Różnica PKB p.c. } \\
\text { (USD) }\end{array}$ & $\begin{array}{c}\text { Różnica } \\
\text { korupcji } \\
\text { (pkt) }\end{array}$ & Państwo & $\begin{array}{c}\text { Różnica PKB p.c. } \\
\text { (USD) }\end{array}$ & $\begin{array}{c}\text { Różnica } \\
\text { korupcji } \\
\text { (pkt) }\end{array}$ \\
\hline Austria & 8325,35 & 1 & Łotwa & 7960,24 & 28 \\
\hline Bułgaria & 3551,25 & 12 & Holandia & 8208,24 & -3 \\
\hline Czechy & 7050,62 & 8 & Norwegia & 11067,73 & -3 \\
\hline Dania & 5521,87 & -9 & Polska & 6776,52 & 16 \\
\hline
\end{tabular}




\begin{tabular}{|c|c|r|c|c|c|}
\hline Estonia & 8485,24 & 13 & Portugalia & 1752,90 & -2 \\
\hline Finlandia & 8461,59 & -6 & Rumunia & 4735,12 & 16 \\
\hline Francja & 5031,83 & 3 & Słowacja & 8315,98 & 12 \\
\hline Niemcy & 9008,96 & 2 & Hiszpania & 4280,42 & -3 \\
\hline Węgry & 4730,38 & 1 & Szwecja & 14067,33 & -6 \\
\hline Islandia & 11523,94 & -14 & Szwajcaria & 11200,59 & -3 \\
\hline Irlandia & 19935,25 & -7 & Turcja & 3622,118 & 8 \\
\hline Włochy & $-669,34$ & -2 & Wlk. Brytania & 8160,952 & -6 \\
\hline
\end{tabular}

Źródło: opracowanie własne.

Analizując przypadek Polski, można zauważyć, że począwszy od 2005 r., nastąpił wyraźny wzrost indeksu percepcji korupcji (rysunek 1). Polska 1 maja 2004 r. przystąpiła do Unii Europejskiej, zaś 21 grudnia 2007 r. została włączona do strefy Schengen. Pogłębiająca się współpraca gospodarcza między państwami europejskimi a Polską w tym okresie doprowadziła do zwiększenia się otwartości naszej gospodarki. W latach 1998-2015 PKB na osobę w Polsce wzrosło o 6776,52 USD, zaś wskaźnik percepcji korupcji zwiększył się o 16 pkt. Widoczne pozytywne skutki w walce z korupcją są połączone z jednoczesnym zwiększeniem otwartości gospodarki oraz zacieśnianiem integracji z państwami należącymi do Unii Europejskiej.

Rysunek 1. Wskaźnik percepcji korupcji (pkt) w latach 1998-2015 dla Polski

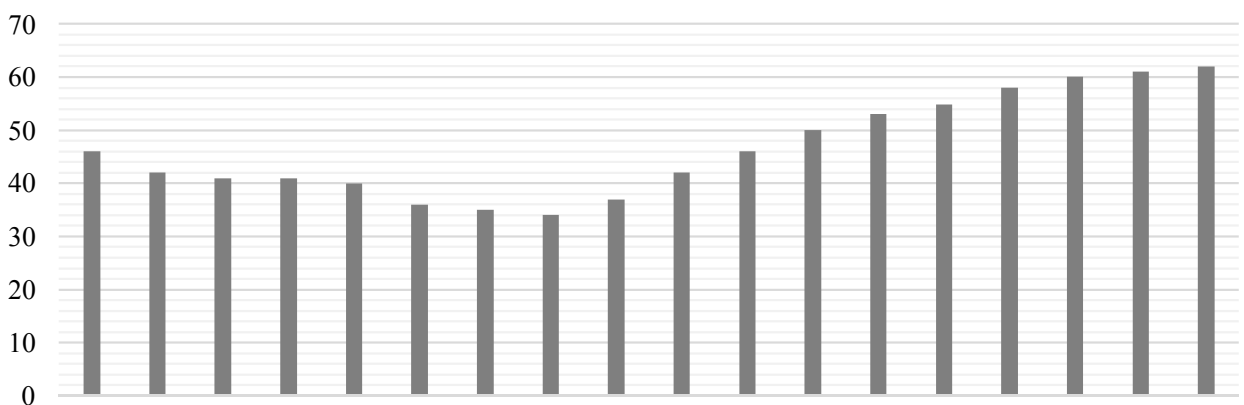

199819992000200120022003200420052006200720082009201020112012201320142015

Źródło: opracowanie własne na podstawie danych Transparency International.

Badanie to nie jest jednak wolne od wad. Po pierwsze, przeprowadzono je na podstawie syntetycznego miernika percepcji korupcji. Indeks percepcji korupcji, mimo że jest uważany przez naukowców za dobry miernik korupcji w sferze publicznej i na jego podstawie przeprowadzane są liczne badania, nie jest w pełni 
doskonały. Należy podkreślić, że korupcja to przykład zjawiska, które nie może być w pełni obiektywnie zmierzone: miary, wskaźniki korupcji często bazuja na subiektywnych odczuciach i przekonaniach, a dotarcie do danych ilościowych dotyczacych rozmiarów korupcji ze zrozumialych powodów jest niezmiennie trudne (Walczak-Duraj 2010, s. 264). Przyczyną tego stanu jest tajność towarzysząca transakcjom korupcyjnym. Po drugie, analizie poddano jedynie miernik rozwoju gospodarczego oraz wskaźniki przepływu kapitału. Nie przeanalizowano wszystkich miar sugerowanych w literaturze, dotyczących m.in. rozwoju konkurencyjności gospodarki czy przepływu informacji. Mierniki te nie zostały uwzględnione w analizie ze względu na brak danych dotyczących wybranych 24 państw w analizowanym okresie.

\section{Zakończenie}

Korupcja, pomimo zachodzących na świecie przemian gospodarczych i kulturowych, nie została wyeliminowana z życia ludności. Istnieje poziom korupcji, który jest akceptowany przez rządzących i społeczeństwo. Co więcej występuje niezerowy poziom korupcji, który sprzyja rozwojowi gospodarczemu. Wynika to z faktu, że korupcja - poza negatywnymi skutkami - ma również pozytywne następstwa.

Powyższa praca prezentuje analizę literatury i badań dotyczących relacji zachodzących między procesami globalizacyjnymi a korupcją. Na podstawie wniosków płynących z literatury postawiono hipotezę o współzależności między rozwojem gospodarczym wynikającym z globalizacji a zmniejszającym się skorumpowaniem. Na przykładzie bazy danych dotyczących 24 państw europejskich wykazano, że w przypadku krajów słabiej rozwiniętych wzrost rozwoju gospodarczego wiązał się ze zmniejszeniem korupcji. Obserwowany jest zatem spadek przyzwolenia na korupcję w sferze publicznej (Elliott 1997, s. 8).

Procesy globalizacyjne nie spowodowały zaniku korupcji, czego można by było się spodziewać po zacieśnianiu więzi między narodami. W wyniku globalizacji następuje otwarcie się gospodarek na współpracę. Ta większa otwartość powinna wymuszać również większą przejrzystość transakcji na globalnym rynku. Wydaje się jednak, że korupcja wpasowała się w te procesy i transakcje - występuje ona w obecnej rzeczywistości gospodarczej, również w przypadku interesów międzynarodowych. Przykładem może być skorumpowanie działaczy FIFA w ostatnich latach. Niewątpliwie procesy globalizacyjne nie wyeliminują zjawiska korupcji, lecz mogą doprowadzić do jej globalnego zmniejszenia lub zmiany jej percepcji. 


\section{Bibliografia}

Badinger H., Nindl E. (2014), Globalisation and corruption, revisited, „The World Economy”, Vol. 37, nr 10, ss. 1424-1440.

Bodislav D., Rotaru C., Georgescu R. (2016), Globalization of the corruption phenomenon - human capital gone wild, „Theoretical and applied economics", Vol. 23, nr 3, ss. 163-176.

Cywilnoprawna konwencja o korupcji sporządzona w Strasburgu dnia 4 listopada 1999 r. (Dz.U. nr 244 poz. 2443).

Dzhumashev R. (2014), Corruption and growth: The role of governance, public spending and economic development, „Economic Modelling”, nr 37, ss. 202-215.

Elliott A. (1997), Corruption and the Global Economy, Institute for International Economics, Waszyngton.

Ewoh A., Matei A., Matei L. (2013), Corruption, public integrity, and globalization in South-Eastern European states. A Comparative analysis, „Theoretical and Applied Economics”, Vol. 20, nr 1, ss. 7-34.

Heckelman J., Powell B. (2010), Corruption and the Institutional Environment for Growth Comparative Economic Studies, Palgrave Macmillan, nr 52(3), ss. 351-378.

Herodot (2008), Dzieje, Czytelnik, Warszawa.

Klitgaard R. (1988), Controlling Corruption, University of California Press, Berkeley.

Lewicka-Strzałecka A. (2007), Korupcja i zaufanie, „Annales. Etyka w życiu gospodarczym", Vol. 10, nr 1, ss. 211-219.

Mindur M. (2006), Korupcja a rola państwa w rozwoju gospodarczym, „Studia i prace kolegium zarządzania i finansów”, nr 74, ss. 75-84.

Stachowicz-Stanusch A., Sworowska A. (2012), Definiowanie korupcji w kontekście różnic kulturowych, „Organizacja i zarządzanie”, $\mathrm{nr} 1$, ss. 97-115.

Torgler B., Piatti M. (2013), Extraordinary wealth, globalization and corruption, „Review of income and Wealth”, Vol. 59, nr 2, ss. 341-359.

Walczak-Duraj D. (2010), Socjologia dla ekonomistów, Polskie Wydawnictwo Ekonomiczne, Warszawa.

www.databank.worldbank.org.

Www.transparency.org.

www.worldbank.org. 


\section{Streszczenie}

Korupcja jest obecna w społeczeństwach od czasów starożytnych. Rozwój gospodarczy i ewoluowanie kultur nie wyparły jej. Należy zatem zadać pytanie: czy globalizacja wspiera korupcję? W artykule zaprezentowano przegląd literatury, który wskazuje na niejednoznaczną odpowiedź na to pytanie. Przeprowadzono analizę statystyczną wybranych wielkości makroekonomicznych w porównaniu do Indeksu Percepcji Korupcji. Wyniki wskazały, że w przypadku państw rozwijających się wzrost rozwoju gospodarczego wiązał się ze zmniejszeniem skorumpowania, jednak go nie wyeliminował. Należy wnioskować, że istnieje poziom korupcji akceptowany przez rząd i społeczeństwo.

Słowa kluczowe: korupcja, globalizacja, rozwój gospodarczy, inwestycje

\section{Summary}

\section{Does globalization support corruption?}

Corruption has been present in societies since ancient times. Economic development and the evolution of culture did not result in elimination of corruption. Therefore, you should ask the question: does globalization promote corruption? The article presents a literature review that points to an ambiguous answer to this question. Statistical analysis of selected macroeconomic values are compared to the Corruption Perceptions Index. The results indicated that, for developing countries, increasing economic growth was associated with a decrease in corruption, but it is not eliminated. It must be concluded that there is a level of corruption that is accepted by governments and society.

Keywords: corruption, globalization, economic development, investment

JEL: D73, O11 